Article

\title{
Diversity and Structure of the Tychoplankton Diatom Community in the Limnocrene Spring Zelenci (Slovenia) in Relation to Environmental Factors
}

\author{
Igor Zelnik*, Tadeja Balanč and Mihael J. Toman \\ Department of Biology, Biotechnical Faculty, University of Ljubljana, Jamnikarjeva 101, \\ SI-1000 Ljubljana, Slovenia; Tadeja.balanc@gmail.com (T.B.); mihael.toman@bf.uni-lj.si (M.J.T.) \\ * Correspondence: igor.zelnik@bf.uni-lj.si; Tel.: +386-1-320-3339
}

Received: 30 January 2018; Accepted: 21 March 2018; Published: 23 March 2018

check for updates

\begin{abstract}
The influence of selected factors on the diversity and composition of tychoplanktonic diatom community in limnocrene spring Zelenci was investigated. The spring that was studied is located in a glacial valley in the south-eastern calcareous Alps. Samples of tychoplankton were collected with a plankton net between October 2012 and August 2015 and for each sample, selected abiotic factors were measured. Over 100 different diatom species were identified, the most abundant being Achnanthidium minutissimum and Denticula tenuis. The most species-rich genera were Navicula, Fragilaria, Nitzschia, Cymbella and Gomphonema. The most significant impact on species composition of tychoplanktonic diatom community was from the conductivity of the water and the consecutive number of the month. Diversity was correlated negatively with concentration of orthophosphate and positively with $\mathrm{pH}$ and water level. Benthic species from the low profile ecological group dominated the tychoplankton community, with a share of 30-72\%. High profile and motile species characteristic for benthos reached higher shares on average than euplanktonic species. This indicates the essential role of underwater springs in the maintenance of a species-rich tychoplanktonic community.
\end{abstract}

Keywords: tychoplankton; pool spring; south-eastern calcareous Alps; river Sava; ecological groups; algae

\section{Introduction}

Freshwater ecosystems cover only $0.8 \%$ of the Earth's surface, but host more than $10 \%$ of all animal species [1]. In general, their contribution to biodiversity is exceptional, but its decline currently exceeds that of other ecosystems [2]. Unlike many freshwater ecosystems, especially rivers, springs are still relatively diverse and natural habitats. Moreover, springs have unique characteristics [3] and are very important for the conservation of aquatic biodiversity [4]. They include many mesohabitats with diverse substrates which enable high biodiversity [3]. Despite this high diversity, spring habitats have not been studied well. Unfortunately, intact springs are becoming increasingly rare, since they are influenced by factors such as nutrient enrichment, exploitation for drinking water and pollution [5].

Springs are highly dependent upon groundwater properties [6,7]. The main physical and chemical properties of the springs, including more or less stable temperature, and conductivity and oxygen content are determined by the relevant aquifers, in which influences of the catchment area are reflected [3]. Since they are the source of streams, downstream events are often associated with the status of springs.

Diatoms are not the major contributors to biomass in springs [5], but they are abundant and play a key role in the functioning of such ecosystems [3] and several endangered and rare species, as well as taxa new to science live in springs [8]. The analysis of diatom communities is also a very useful 
tool with which to assess ecological status. As stated by Cantonati et al. [4] it would be worthwhile to define the reference diatom communities of springs.

The distribution of diatoms is strongly influenced by the type of bedrock and the latitude, which have indirect impacts on the properties of the water. The importance of environmental, spatial and historical factors on diatom communities depends upon the extent of the study area [9]. At the local level (e.g., spring), the heterogeneity is defined by the variability of environmental factors such as light intensity, grazing, succession stage and substrate [9]. Typical spring communities develop in springs with slower water current while in springs with fast flowing water widespread rheophilous species occur [3]. In pool springs, where current velocity does not have a significant impact on the composition of the communities, factors such as $\mathrm{pH}$, conductivity, inorganic nitrogen content, substrate texture, light and temperature are important [10]. Spring diatoms have been studied in several parts of the Alpine region [3,11-15], as well as in other mountainous regions in Europe [16-18].

Limnocrene springs are extremely species-rich $[11,13]$. Slow flowing water in such springs enables the accumulation of finer sediments and colonization of several mesohabitats, so the diversity is higher and communities are more specific [16]. Underwater springs in the pool create specific conditions for diatoms as well as various organisms, because vertical currents occur where the water emerges through the sediments, and these cause the raising of the fine-grained sediments and transfer of benthic organisms into the water column. Vertical currents enable the establishment of tychoplanktonic diatom communities, which are a characteristic of pool springs. Tychoplankton is a poorly defined group of mostly immobile non-attached diatoms living between the sediment particles. A majority of diatoms which form tychoplanktonic communities are primarily benthic but may enter the water column via currents and live temporarily as plankton [19].

The aim of the present study was to find out whether the underwater springs support the diatom community in the water column and whether the structure and diversity of tychoplanktonic diatom community in pool spring Zelenci changes during the seasons. We hypothesized that (a) tychoplankton contains a high number of diatom species due to vertical currents and low temperatures throughout the year; (b) the species composition and diversity of diatom community is affected by environmental factors and by the time of year; and (c) benthic species are much more abundant than euplanktonic species in the water column, due to strong upwelling.

\section{Materials and Methods}

\subsection{Study Site}

Zelenci is a $0.54 \mathrm{~km}^{2}$ large wetland in the Alpine valley in NW end of Slovenia at an altitude of $834 \mathrm{~m}$ a.s.l., which was declared a special protection area of Natura 2000. We studied the biggest pool spring within the wetland complex, which is regarded as the source of the Sava River, itself a tributary of the Danube. Mountain ranges around the valley are a part of the south-eastern calcareous Alps. In the last glacial period, some 10,000 years ago, a glacier covered this area and after it melted, a lake formed at its end moraine. The ancient lake covered the entire wetland area and thick layers of chalk-silt deposits were accumulated. The majority of the water feeding these springs comes from the Planica Valley to the SW, which is surrounded by the Julian Alps. Streams running into the valley sink into the stony deposits and flow under the surface to the lowest area in front of the moraine when they form a well with several springs. Some portion of the water finds its way to the surface in a $1400 \mathrm{~m}^{2}$ pool spring, where it streams out from the silty bottom in numerous small underwater springs that resemble small "volcanoes" [20].

The sampling site at $46^{\circ} 29^{\prime} 33.1^{\prime \prime} \mathrm{N}, 13^{\circ} 44^{\prime} 45.1^{\prime \prime} \mathrm{E}$ is in the deeper hollow in front of a pier. The depth of the water there is $2-3 \mathrm{~m}$ and the stable bottom around the sampled hollow is overgrown with water buttercup (Ranunculus trichophyllus). The number and intensity of active small underwater "microsprings" varies according to hydrological conditions. In August and October 2014, there were 
around 15 microsprings each measuring $20 \mathrm{~cm}$ in diameter. In April and June 2015, just two active underwater microsprings were observed in this hollow.

\subsection{Sampling and Laboratory Analyses}

Sampling was carried out from October 2012 to October 2013 and from August 2014 to August 2015, in approximately two-month intervals, and 13 samples were collected. Semi-quantitative planktonic samples were obtained by diagonal towing of a plankton net [21]. The net was thrown into the water 4 meters from the end of the pier. When it sunk at least half-way to the bottom it was pulled in a transverse direction. This procedure was performed three times and the fourth time an upper layer pull was performed.

At each sampling, the $\mathrm{pH}$, water level, water temperature, conductivity, oxygen concentration and saturation were measured with a multimeter (EUTECH, PCD 650). Water samples were collected and analysed in the laboratory. The cuvette tests HACH Lange were performed for the content of ammonium ions (LCK 304), nitrate (LCK 339) and orthophosphate (LCK 349). Concentrations were measured with a spectrophotometer HACH Lange LT 200.

Samples of tychoplankton were homogenized with a magnetic stirrer and a $5 \mathrm{~mL}$ subsample was boiled with $65 \%$ nitric acid to remove organic matter. Permanent slides were prepared by mounting cleaned frustules with Naphrax ${ }^{\circledR}$.

Diatoms were identified at $1000 \times$ magnification (oil immersion) using an Olympus CX41 microscope. Due to scarcity of diatoms in some samples, 200 frustules were determined and counted in each sample. Diatom species were identified with keys published by Hofmann et al. [22], Krammer and Lange-Bertalot [23]. Nomenclature of diatom taxa follows Hofmann et al. [22], with the exception of species from the genera Cyclotella, Stephanodiscus and Aulacoseira where we followed Krammer and Lange-Bertalot [23].

\subsection{Ecological Groups of Diatoms}

Diatom species were classified into ecological groups or "guilds" according to Passy [24] and Rimet and Bouchez [25]. Grouping species to ecological guilds can strengthen relations with certain environmental stressors or factors, when compared to species data [25]. We agree with Stenger-Kovács et al. [26] who stated that the meaning of ecological groups of diatoms is strong enough to be an appropriate indicator of changing environmental conditions on temporal gradient. In analogous analyses in vascular plants, several researchers reported that ecological functions of the communities are better described by functional groups than by species composition $[27,28]$. Considering this analogy we also use the term ecological groups instead of guilds, as suggested by Tapolczai et al. [29]. Rimet and Bouchez [25] divided diatom species into four groups according to their ecological strategies, life forms, cell sizes and/or efficiency of movement: planktonic, low profile, high profile and motile groups. Planktonic species are adapted to a lentic environment in a way which slows down their sedimentation and they have usually thinner frustules than benthic species.

The low profile group includes slowly moving species and species which are linked to the substrate with a valve face or attached only at the pole and are mounted diagonally or vertically. Species classified in this group are more resistant than others to physical disturbance, for example turbulent water, but they do not prefer high levels of nutrients [24]. This ecological group is dominant at sites with low nutrients and scarce resources [24,30].

The high profile group includes species with larger cells, stalked species or species that form various types of colonies. Members of this group are sensitive to physical disturbance, but are favoured by high nutrient concentrations [24,25].

The group of motile, or fast moving species includes species capable of effective movement, which mostly glide in upper layers of the periphyton. They are adapted to turbulent environments [24], including disturbances due to turbulence and fast water flow and to high nutrient levels. Their ability to adapt to active movement enables their selection of the most appropriate microhabitat [31]. 


\subsection{Data Analyses}

As a measure of diversity, species richness, or the number of species per sample was used and Shannon-Wiener diversity index (SWI) was calculated.

The influence of selected environmental factors on the composition of the diatom community was checked by direct gradient analysis. Before the analyses, we grouped diatom species data by ecological groups and a simplified matrix was used to represent the tychoplankton community structure. First, we conducted a detrended correspondence analysis (DCA), which showed a linear distribution and slow turnover of data along potential gradients (gradient length $=1.7$ Standard Deviations), see ter Braak and Verdonschot [32], and we used redundancy analysis (RDA). Analyses were performed with the software package CANOCO 4.5 [33]. We checked with RDA the relationships between community composition and selected factors, and the share of the variability they account for. This was conducted with a series of RDAs. The impact of environmental factors on community composition was examined by forward selection of variables with 999 permutations, which was used to provide the ranking of the relative importance of specific explanatory variables [33] and to avoid co-linearity as suggested by Hudon et al. [34]. The shares of ecological types of diatoms in the samples were log transformed. Only those variables which had statistically significant effect $(p<0.05)$ were accounted for. Twelve samples were used in these analyses. The ordination diagram, shown in Figure 1 was created on the basis of the results of RDA with environmental variables that significantly affected community composition.

Correlations between variables were tested with a Kendall tau $(\tau)$ rank correlation coefficient. This analysis was conducted using PAST [35].

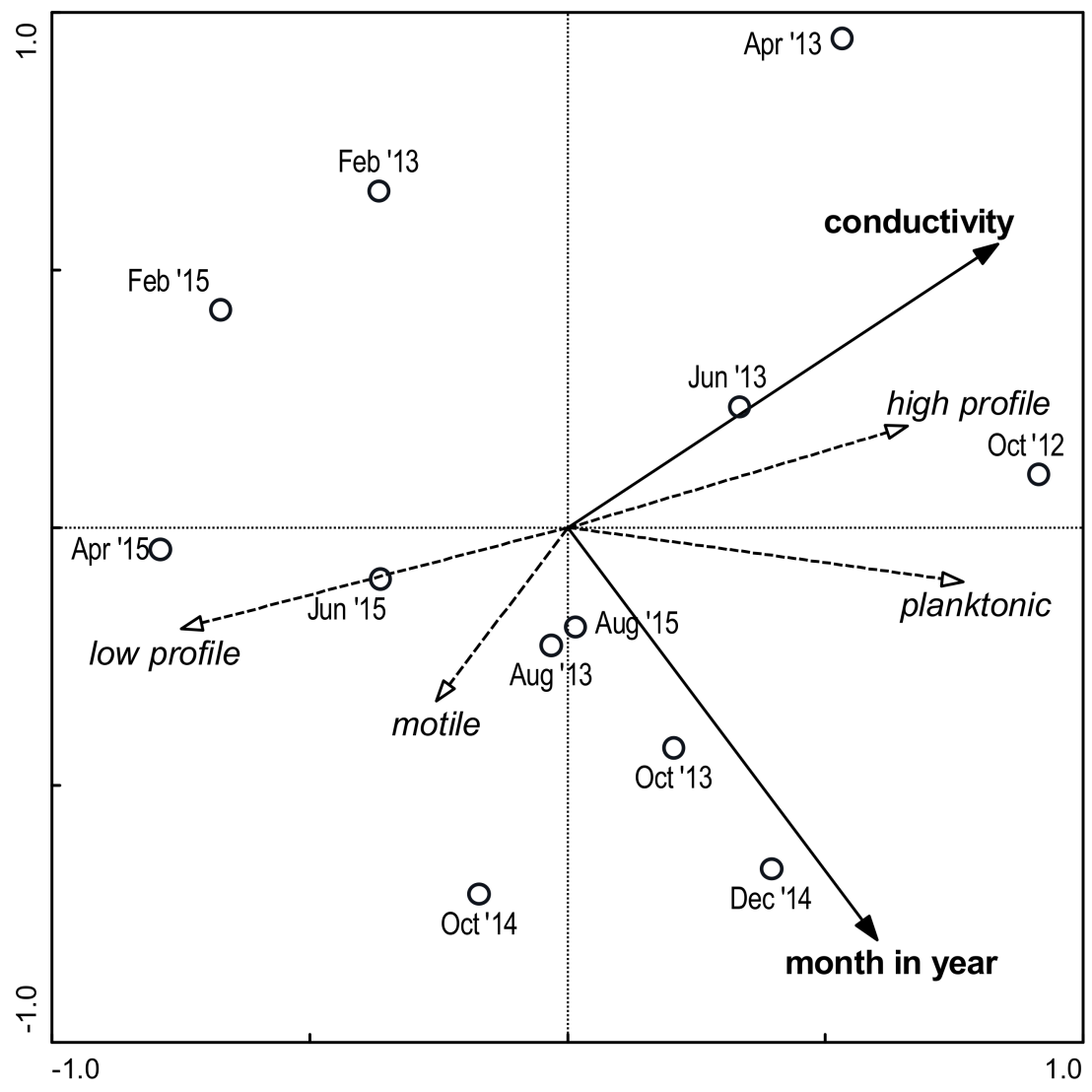

Figure 1. Ordination diagram as a result of redundancy analysis (RDA) with factors that significantly influenced the structure of tychoplanktonic community. The cumulative percentage variance of ecological groups for the first axis was $52 \%$ and $54.6 \%$ for the second axis. Circles represent specific samples. 


\section{Results}

\subsection{Abiotic Factors}

The highest water level was found in the sample from December 2014, and the lowest was in April 2015. The difference between the lowest and highest measured temperature was $4.7^{\circ} \mathrm{C}$ (Table 1 ). Measured $\mathrm{pH}$ values (7.2-7.8) showed a slightly alkaline environment. The average conductivity of water was $257 \mu \mathrm{S} / \mathrm{cm}( \pm 10 \%)$.

Table 1. Minimal, maximal and average values of environmental parameters and ecological groups of tychoplanktonic diatom community. LP-low profile species, $\mathrm{HP}$ - high profile species, M-motile species, PL—planktonic species, * — concentration below detection.

\begin{tabular}{cccc}
\hline & Min & Max & Average \\
\hline $\mathrm{pH}$ & 7.2 & 7.8 & 7.6 \\
$\mathrm{~T}\left[{ }^{\circ} \mathrm{C}\right]$ & 5.3 & 9.6 & 7.4 \\
conductivity $[\mu \mathrm{S} / \mathrm{cm}]$ & 234 & 290 & 257 \\
$\mathrm{O}_{2}$ saturation $[\%]$ & 80 & 103 & 88 \\
$\mathrm{O}_{2}[\mathrm{mg} / \mathrm{L}]$ & 9.1 & 11.7 & 10 \\
$\mathrm{PO}_{4}{ }^{3-}[\mathrm{mg} / \mathrm{L}]$ & $*$ & 0.12 & 0.027 \\
$\mathrm{NH}_{4}+[\mathrm{mg} / \mathrm{L}]$ & 0.016 & 0.817 & 0.334 \\
$\mathrm{NO}_{3}-[\mathrm{mg} / \mathrm{L}]$ & 1.5 & 2.8 & 2.0 \\
$\mathrm{water} \mathrm{level}[\mathrm{cm}]_{\mathrm{LP} \%}$ & 65 & 118 & 89 \\
$\mathrm{HP} \%$ & 30 & 72 & 51 \\
$\mathrm{M} \%$ & 12 & 39 & 19 \\
$\mathrm{PL} \%$ & 15 & 33 & 23 \\
\hline
\end{tabular}

The concentration of $\mathrm{PO}_{4}{ }^{3-}$ varied considerably over the seasons. The concentrations of all measured nutrients maximized in August 2014 and October 2014 (Table 1).

\subsection{Diatom Species Richness}

In total, 103 different diatom species were identified. The individual samples of tychoplankton species contained were between 24 on February 2014 and 47 on October 2014. Values of SWI were relatively high, but they varied considerably over time, from 3.17 to 4.58 . The most species-rich genera were: Navicula (13 spp.), Fragilaria (9 spp.), Nitzschia (8 spp.), Cymbella (8 spp.) and Gomphonema (6 spp.).

\subsection{Environmental Factors and Species Composition}

The RDA revealed that the composition of tychoplanktonic community was influenced statistically significantly by conductivity of the water and month of the year (Figure 1). Together, these factors explain $55 \%$ of the variability of species composition. Around $37 \%$ of the total variance was explained by conductivity and $18 \%$ with the month of the sampling.

A minor share of tychoplanktonic community (0-20\%) consisted of euplanktonic species. They were far less common than benthic species (Table 1, Figure 2). Among benthic species, the most abundant ecological type was the low profile group (30-72\%). Motile species and high profile species had considerably lower shares ( $23 \%$ and $25 \%$ on average), and except in three samples the planktonic species were less common than any of the three ecological types of benthic species (Figure 2).

The analysis of correlations (Table 2) revealed that proportions of high profile species and planktonic species were statistically significantly positively correlated with conductivity, while the response of low profile species was the opposite. These relations can be seen also on the ordination diagram (Figure 1). The share of low profile species was positively correlated with oxygen saturation, which indicates their preference to environment with a low content of electrolytes and good oxygenation. 


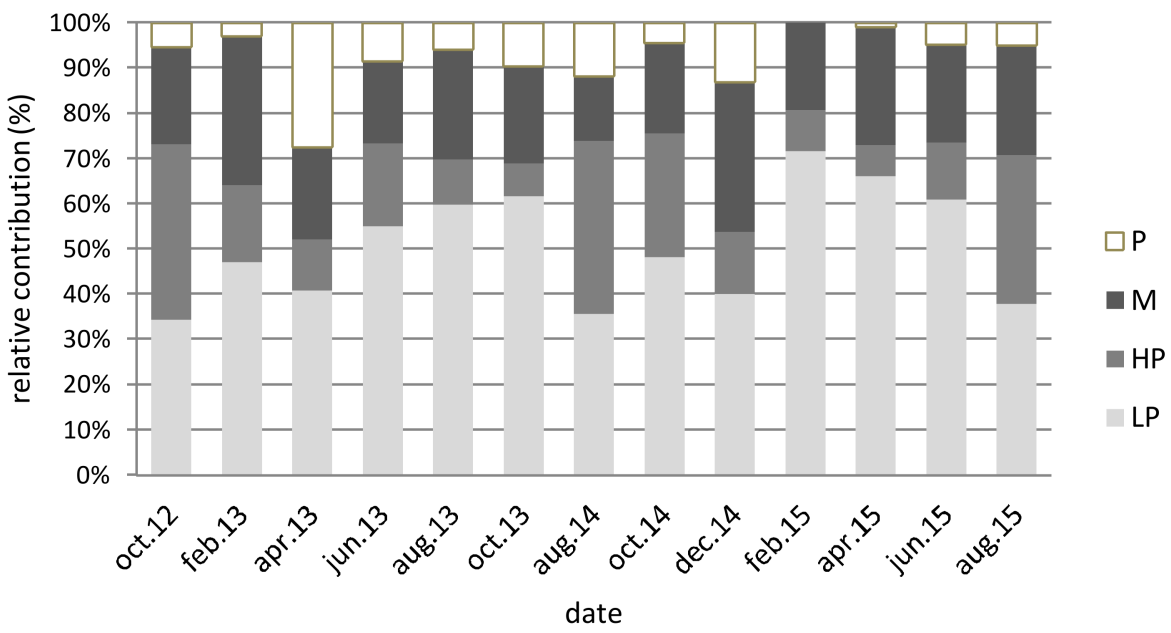

Figure 2. The shares or relative contributions of ecological groups of diatoms in the tychoplankton community in different months. LP—low profile species, HP—high profile species, $\mathrm{M}$-motile species, $\mathrm{P}$ - planktonic species.

Table 2. Kendall's rank correlation coefficients $(\tau)$ between environmental parameters and ecological groups as well as diversity of the tychoplanktonic diatom community. LP-low profile species, $\mathrm{HP}$ —high profile species, $\mathrm{M}$-motile species, $\mathrm{PL}$ - planktonic species. SWI-Shannon-Wiener diversity index; coefficients in bold are significant $(p<0.05)$.

\begin{tabular}{ccccccc}
\hline & LP [\%] & HP [\%] & M [\%] & PL [\%] & Nr. spp. & SWI \\
\hline $\mathrm{pH}$ & 0.099 & -0.017 & -0.253 & 0.261 & $\mathbf{0 . 4 5 8}$ & 0.230 \\
$\mathrm{~T}\left[{ }^{\circ} \mathrm{C}\right]$ & 0.168 & -0.031 & 0.000 & 0.000 & -0.142 & -0.351 \\
conductivity $[\mu \mathrm{S} / \mathrm{cm}]$ & $-\mathbf{0 . 5 4 5}$ & $\mathbf{0 . 5 0 4}$ & -0.171 & $\mathbf{0 . 4 6 5}$ & 0.250 & 0.242 \\
$\mathrm{O} 2$ saturation $[\%]$ & $\mathbf{0 . 5 0 4}$ & -0.400 & 0.125 & -0.291 & -0.110 & -0.107 \\
$\mathrm{O} 2[\mathrm{mg} / \mathrm{L}]$ & 0.326 & -0.313 & 0.000 & 0.082 & 0.192 & 0.295 \\
$\mathrm{PO}_{4}{ }^{3-}[\mathrm{mg} / \mathrm{L}]$ & -0.031 & 0.016 & -0.016 & -0.281 & $-\mathbf{0 . 6 4 5}$ & $\mathbf{- 0 . 5 0 0}$ \\
$\mathrm{NH}_{4}+[\mathrm{mg} / \mathrm{L}]$ & -0.064 & -0.016 & -0.146 & $\mathbf{0 . 5 0 4}$ & 0.377 & 0.191 \\
$\mathrm{NO}_{3}-[\mathrm{mg} / \mathrm{L}]$ & 0.333 & $-\mathbf{0 . 4 4 3}$ & $\mathbf{0 . 4 5 0}$ & -0.112 & -0.250 & -0.030 \\
potential irradiance & 0.080 & 0.065 & -0.197 & 0.153 & 0.017 & -0.208 \\
month in the year & -0.286 & 0.176 & 0.049 & 0.403 & 0.164 & 0.413 \\
month of sampling & 0.333 & -0.351 & 0.171 & -0.208 & -0.375 & -0.273 \\
water level & -0.394 & 0.321 & -0.326 & $\mathbf{0 . 4 9 7}$ & 0.406 & $\mathbf{0 . 5 1 5}$ \\
\hline
\end{tabular}

\section{Discussion}

\subsection{Abiotic Factors}

The difference between the highest and the lowest measured temperature of the water over the year was $4.3{ }^{\circ} \mathrm{C}$, which is quite large for springs [11,12]. Seasonal fluctuation of temperature is a consequence of water retention in the pool, which is exposed to the sun and can become warmer in the summer [12,36], but is also cooled down by cold air during the winter.

Oxygen saturation was 62-88\%, slightly higher than in mountain limnocrene springs in the Italian part of the southern calcareous Alps [11], while Menegalija and Kosi [12] reported significantly higher values (e.g., 125\%) from the Julian Alps in Slovenia, but the substrate there is overgrown with epilithon, which contributes to higher oxygen saturation. Lower values measured in August are associated with increased levels of ammonium ions, which is probably the result of organic pollution.

The water was slightly alkaline. According to classification by van Dam et al. [37], 66\% of recorded species were alkalophilic, $27 \%$ were circumneutral and 5\% acidophilous. Small variations in 
$\mathrm{pH}$ reflected high buffering capacity, which is typical for water on carbonate bedrock [38]. Similar $\mathrm{pH}$ values were also measured in limnocrene springs by Menegalija and Kosi [12].

A high electric conductivity $(234-290 \mu \mathrm{S} / \mathrm{cm})$, characteristic for carbonate bedrock [10-12,16,39] was measured throughout the year.

Spring water usually has a very low content of orthophosphate [3]. In mountain limnocrene springs, orthophosphate concentrations range from 0.003 to $0.006 \mathrm{mg} / \mathrm{L}[10,12,40]$. With a few exceptions, values measured in the present study were in this interval. Higher concentrations, up to $0.27 \mathrm{mg} / \mathrm{L}$ were measured in August 2014 and October 2014, indicating human influence.

Levels of nitrates in mountain springs usually range up to $3 \mathrm{mg} / \mathrm{L}[3,11,12]$. Significant fluctuation in the concentrations of $\mathrm{NO}_{3}{ }^{-}$indicates human impact, including agriculture and seasonal tourism $[3,12]$. Our results were always $<3 \mathrm{mg} / \mathrm{L}$, indicating that the spring was not burdened with $\mathrm{NO}_{3}{ }^{-}$.

Concentrations of $\mathrm{NH}_{4}{ }^{+}$ions in the uncontaminated water are $<0.063 \mathrm{mg} / \mathrm{L}$ [3]. If the concentration exceeds $0.038 \mathrm{mg} / \mathrm{L}$ organic pollution is indicated [3]. Most of the measured concentrations of ammonium ions were $<0.05 \mathrm{mg} / \mathrm{L}$, which is similar to the values measured in springs in the Italian Alps [11,40]. The exceptions were samples taken on August 2014 and October 2014 when values increased to $0.65 \mathrm{mg} / \mathrm{L}$, indicating recent organic pollution.

\subsection{Diversity of the Tychoplanktonic Community}

A total of 103 diatom species were identified which was higher than numbers reported in the literature. Aboal et al. [17] report 11-51 species per spring studied in eastern Spain, whereas Cantonati and Ortler [41] report 9-54 diatom species per spring in the southern Italian Alps. Considering these data, the Zelenci spring was very species-rich, and $24-47$ diatom species were found per single sample, indicating a good conservation status [42].

One of the reasons for high diversity might be the exposure to full sun and relative stability of the hydrological conditions. Sun-exposed springs and springs with relatively constant conditions, which can be also found in the Zelenci spring, are characterized by a greater species diversity [12].

The present results are somewhat contradictory in the case of temporal distribution of species richness. The highest species number was recorded in May 2013, but on the contrary, the sample June 2015 contained almost the lowest number of species. We considered the species-poorest sample June 2015 to be an outlier, since Cantonati [11] reports the highest number of species for late spring or early summer.

The values of SWI ranged between 3.17 and 4.58 and were much higher than previously reported. Cantonati [11] reports lower values of this index $(\sim 2)$ for benthic diatom communities in springs in Southern Alps and Menegalija and Kosi [12] report values from 1.6 to 2.04 for springs in Julian Alps. Higher values of SWI for the spring diatom communities of eastern Spain (2.1-3.8) have been reported by Aboal et al. [17]. However, the spring under study is permanent, includes different habitats and is exposed to direct sunlight which is a favourable condition according to energy theory. The flow of water in the spring was slow and disturbance frequency and/or intensity was not high, but still enough to prevent competitive exclusions.

Active underwater springs on the bottom of the hollow contribute to the high diversity, since vertical currents generate constant disturbances and create dynamic and unstable conditions on the sediments as well as in the water column, where the tychoplanktonic diatom community thrives. Moderate disturbances prevent competitive exclusion in the benthic phase and enable the coexistence of numerous species from different ecological groups which form species-rich communities. That is in accordance with the intermediate disturbance hypothesis [43], which suggests that species diversity is maximal when disturbances are at moderate frequency/intensity enabling the coexistence of species with different life strategies. Lengyel et al. [31] also connected the highest diversity of benthic diatoms with disturbance high enough to enable the coexistence of various strategists.

The lowest diversity was found in a sample taken on February 2015, a sample which was also the poorest in species (24). Menegalija and Kosi [12] suggested the lack of nutrients as the main reason for 
low number of species in alpine springs. However, the number of diatom species in springs that have been studied was negatively correlated with the concentration of orthophosphate. Species richness has been often found in correlation with factors representing a trophic state [44].

The value of the SWI was also negatively correlated with the orthophosphate content, but in positively correlated with the water level (Table 2). Higher water level indicates recent increase of vertical flow as well as the increase of the sediments and benthic diatoms subjected to upwelling currents which support the tychoplankton community.

\subsection{Environmental Factors and Species Composition}

Significant impact on species composition was calculated for conductivity and the month of the year, which represents a temporal dimension. The importance of conductivity is in accordance with findings of Cantonati [11] who reports that species composition of diatom communities in springs is mostly influenced by $\mathrm{pH}$ and conductivity. Conductivity is the factor most frequently reported to shape the structure of periphytic diatom communities [26,45]. Diatoms in springs are also strongly influenced by nutrients and the intensity of solar irradiation [12,41]. Cantonati and Pipp [46] report that seasonality of diatoms in springs coincides with changes of discharge and nutrient concentrations.

Species composition did not change much between the seasons. Samples had at least $50 \%$ of the same taxa, while the most similar samples consisted of up to $70 \%$ of the same taxa. Absence of significant changes in diatom species composition in springs during the year, especially on carbonates has been reported by Cantonati and Pipp [46].

The most abundant taxon was Achnanthidium minutissimum (8-37\%) which was the most characteristic species for springs [10,17], as well as the most abundant [3]. The second most abundant species was Denticula tenuis, the most common in springs in the Pyrenees [16]. The second most common diatom in Alpine springs is Diatoma mesodon [11], but in our case it was dominant only in the sample August 2015, which stands out because of low concentrations of $\mathrm{NH}_{4}{ }^{+}$and $\mathrm{NO}_{3}{ }^{-}$.

\subsection{Correlations between Factors and Ecological Groups}

The proportions of high profile species and planktonic species were significantly positively correlated with conductivity, while the share of low profile species was negatively correlated with conductivity (Figure 1, Table 2).

The share of planktonic species was low (Table 1 ), as a result of the short residence time of water. Planktonic species were positively correlated with the water level $(\tau=0.497$; Table 2$)$, since a larger volume of water in the pool favours them. B-Béres et al. [47] report that planktonic groups were positively correlated with temperature and nutrients.

Constant disturbances favour low profile species, which were the largest component $(51 \%$ on average; Table 1) of tychoplankton. This group includes also pioneer species [25], which are common in the springs. Two pioneer species from the genus Amphora (A. inariensis and A. pediculus) were found in tychoplankton, while Achnanthidium minutissimum was the most abundant species. The reason for high abundance of benthic pioneer species in tychoplankton is their ability to be the fastest colonizers of bare substrate [47] adjacent to the microsprings which most frequently drift upwards into the water column before the late-successional high profile and motile species could out-compete them.

A positive correlation of low profile group and oxygen saturation was calculated, and the correlation with conductivity was negative (Table 2) indicating their affinity for high oxygenation of water and low content of electrolytes. Porter et al. [48] report that abundance of taxa with continuously high dissolved oxygen requirements decreases significantly with increase in nutrients.

In contrast, high profile species are sensitive to disturbances [26] and on average are the lowest shares of benthic ecological groups (Table 2). The occurrence of higher shares of low and high profile species in contrasting conditions (Figure 1) has been reported by Lange et al. [30] and Stenger-Kovács et al. [26]. 
The shares of high profile and motile species, characteristic for the epipelon diatom community [49], were significantly lower (Table 1; 20-23\%). These species are much more sensitive to physical disturbances and slowly colonize unstable sediments around the springs-holes. They drift into the water column less, since many of them are considered as late-successional species [31]. Smucker and Vis [50] report that motile species increase with higher sewage levels, while high profile species decrease. Such a situation in the case of nitrate concentration was calculated in our case (Table 2).

The proportion of motile species also indicates loading of fine sediment [51], which was much lower than in an epipelic diatom community sampled in the same pool [52]. Stenger-Kovács et al. [26] report that the motile group is positively correlated with lower temperatures and is tolerant to nitrates.

The different or sometimes contradictory findings discussed above could be explained by the lack of thick biofilm where some of findings from the literature were confirmed and by specific conditions in the studied pool spring as well as in the tychoplanktonic diatom community.

\subsection{Biodiversity Conservation and Water Resource Management}

Intensification of land use and touristic/recreational use, eutrophication or worsening of trophic status, habitat alteration, changes in run-off patterns or water flow will lead to further decline of freshwater biodiversity $[1,44,53]$.

These findings should be considered when evaluating the impacts of proposed projects. For example, the construction of international gas-pipeline South Stream, section M10, planned to go through this valley would completely change the hydrology and trophic status of the spring Zelenci. The excavation and reinforcement of a $2.5-\mathrm{m}$ deep channel would separate the spring from its major water sources and destroy a 40-m wide corridor [54]. This would divert a great portion of the water and cause a decline in activity of subsurface springs. The concentrations of nutrients in the pool would probably increase due to lower discharge and negatively influence the diversity of tychoplanktonic diatom community, which was also confirmed in our study (Table 2) where the concentration of $\mathrm{PO}_{4}{ }^{3-}$ negatively correlated with both biodiversity indices, while water level positively correlated with SWI. So, the high diversity of diatom tychoplankton community is very vulnerable and protection of the area as a Natura 2000 site is not enough for its conservation, since the potential impacts beyond its boundaries would affect the biodiversity.

\section{Conclusions}

Over 100 diatom species were determined in the tychoplanktonic community, confirming the essential role of underwater springs. The composition of the tychoplanktonic diatom community was significantly influenced by the conductivity of the water and month in the year. Accordingly, environmental conditions as well as the time of year shape the structure of this community. Species-richness and diversity were negatively correlated with phosphorous concentrations.

The proportion of benthic species in the water column was very high $(80-100 \%)$, due to active underwater springs and relatively strong vertical currents. Typical planktonic diatom species were present in tychoplankton, but the low profile benthic species predominated.

Eutrophication, habitat destructions and water-flow alterations are major stressors to freshwater, threatening the quality and availability of water, as well as biodiversity.

Acknowledgments: We are very grateful to Sandra Bizjak who helped at fieldwork and in the laboratory. We also thank to Gorazd Kosi for help in diatom identification. Special thanks go to Mateja Germ for her comments that improved the manuscript. We also thank to Prof. Bill Milne who provided language help. This work was partly funded by the Ministry of Education, Science and Sport, Republic of Slovenia, through the program Biology of Plants [P1-0212].

Author Contributions: Igor Zelnik and Mihael J. Toman conceived and designed the experiments; Tadeja Balanč collected and analysed the samples. Igor Zelnik performed data analysis. Tadeja Balanč and Igor Zelnik wrote the paper with input from Mihael J. Toman.

Conflicts of Interest: The authors declare no conflict of interest. 


\section{References}

1. Stendera, S.; Adrian, R.; Bonada, N.; Cañedo-Argüells, M.; Hugueny, B.; Januschke, K.; Pletterbauer, F.; Hering, D. Drivers and stressors of freshwater biodiversity patterns across different ecosystems and scales: A review. Hydrobiologia 2012, 696, 1-28. [CrossRef]

2. Dudgeon, D.; Arthington, A.H.; Gessner, M.O.; Kawabata, Z.I.; Knowler, D.J.; Leveque, C.; Naiman, R.J.; Prieur-Richard, A.H.; Soto, D.; Stiassny, M.L.J.; et al. Freshwater biodiversity: Importance, threats, status and conservation challenges. Biol. Rev. 2006, 81, 163-182. [CrossRef] [PubMed]

3. Cantonati, M.; Gerecke, R.; Bertuzzi, E. Springs of the Alps-Sensitive ecosystems to environmental change: From biodiversity assessments to long-term studies. Hydrobiologia 2006, 562, 59-96. [CrossRef]

4. Cantonati, M.; Angeli, N.; Bertuzzi, E.; Spitale, D.; Lange-Bertalot, H. Diatoms in springs of the Alps: Spring types, environmental determinants, and substratum. Freshw. Sci. 2012, 31, 499-524. [CrossRef]

5. Mogna, M.; Cantonati, M.; Andreucci, F.; Angeli, N.; Berta, G.; Miserere, L. Diatom communities and vegetation of springs in the south-western Alps. Acta Bot. Croat. 2015, 74, 265-285. [CrossRef]

6. Kløve, B.; Ala-Aho, P.; Bertrand, G.; Boukalova, Z.; Ertürk, A.; Goldscheider, N.; Ilmonen, J.; Karakaya, N.; Kupfersberger, H.; Kvoerner, J.; et al. Groundwater dependent ecosystems. Part I: Hydroecological status and trends. Environ. Sci. Policy 2011, 14, 770-781. [CrossRef]

7. Cantonati, M.; Segadelli, S.; Ogata, K.; Tran, H.; Sanders, D.; Gerecke, R.; Rott, E.; Filippini, M.; Gargini, A.; Celico, F. A global review on ambient Limestone-Precipitating Springs (LPS): Hydrogeological setting, ecology, and conservation. Sci. Total Environ. 2016, 568, 624-637. [CrossRef] [PubMed]

8. Cantonati, M.; Lange-Bertalot, H.; Scalfi, A.; Angeli, N. Cymbella tridentina sp. nov. (Bacillariophyta), a crenophilous diatom from carbonate springs of the Alps. J. N. Am. Benthol. Soc. 2010, 29, 775-788. [CrossRef]

9. Soininen, J. Environmental and spatial control of freshwater diatoms-A review. Diatom Res. 2007, 22, 473-490. [CrossRef]

10. Cantonati, M.; Spitale, D. The role of environmental variables in structuring epiphytic and epilithic diatom assemblages in springs and streams of the Dolomiti Bellunesi national park (south-eastern Alps). Fundam. Appl. Limnol. 2009, 174, 117-133. [CrossRef]

11. Cantonati, M. Diatom communities of springs in the Southern Alps. Diatom Res. 1998, 13, 201-220. [CrossRef]

12. Menegalija, T.; Kosi, G. Distribution of diatoms in springs in the Julian Alps (NW Slovenia). Nat. Slov. 2008, 10, 21-37.

13. Cantonati, M.; Lange-Bertalot, H. Diatom biodiversity of springs in the Berchtesgaden National Park (north-eastern Alps, Germany), with the ecological and morphological characterization of two species new to science. Diatom Res. 2010, 25, 251-280. [CrossRef]

14. Gesierich, D.; Kofler, W. Epilithic diatoms from rheocrene springs in the eastern Alps (Vorarlberg, Austria). Diatom Res. 2010, 25, 43-66. [CrossRef]

15. Taxböck, L.; Linder, H.P.; Cantonati, M. To What Extent Are Swiss Springs Refugial Habitats for Sensitive and Endangered Diatom Taxa? Water 2017, 9, 967. [CrossRef]

16. Sabater, S.; Roca, J.R. Ecological and biogeographical aspects of diatom distribution in Pyrenean springs. Br. Phycol. J. 1992, 27, 203-213. [CrossRef]

17. Aboal, M.; Puig, M.A.; Prefasi, M. Diatom assemblages in springs in Castellón province, Eastern Spain. Algological Stud. 1998, 90, 79-95.

18. Werum, M.; Lange-Bertalot, H. Diatoms in Springs from Central Europe and Elsewhere under the Influence of Hydrogeology and Anthropogenic Impacts; A.R.G. Gantner Verlag K.G.: Ruggell, Liechtenstein, 2004; p. 480.

19. Koh, C.; Khim, J.S.; Araki, H.; Yamanishi, H.; Mogi, H.; Koga, K. Tidal resuspension of microphytobenthic chlorophyll $a$ in a Nanura mudflat, Saga, Arieke Sea, Japan: Flood-ebb and spring-neap variations. Mar. Ecol. Pror. Ser. 2006, 312, 85-100. [CrossRef]

20. Gregori, J. Zelenci-Natural Reserve; Janez Gregori: Ljubljana, Slovenia, 1994; pp. 1-120.

21. Quiroga, M.V.; Unrein, F.; Gonzalez Garraza, G.; Kuppers, G.; Lombardo, R.; Marinone, M.C.; Menu Marque, S.; Vinocur, A.; Mataloni, G. The plankton communities from peat bog pools: Structure, temporal variation and environmental factors. J. Plankton Res. 2013, 35, 1234-1253. [CrossRef] 
22. Hofmann, G.; Werum, M.; Lange-Bertalot, H. Diatomeen im Süsswasser-Benthos von Mitteleuropa. Bestimmungsflora Kieselalgen für die Ökologische Praxis. Über 700 der Häufigsten Arten und Ihre Ökologie; A.R.G. Gantner Verlag K.G.: Ruggell, Liechtenstein, 2011; p. 908.

23. Krammer, K.; Lange-Bertalot, H. Bacillariophyceae. Teil 1-4; Gustav Fischer Verlag: Stuttgart, Germany; New York, NY, USA, 1991.

24. Passy, S.I. Diatom ecological guilds display distinct and predictable behavior along nutrient and disturbance gradients in running waters. Aquat. Bot. 2007, 86, 171-178. [CrossRef]

25. Rimet, F.; Bouchez, A. Life-forms, cell-sizes and ecological guilds of diatoms in European rivers. Knowl. Manag. Aquat. Ecosyst. 2012, 406, 1-12. [CrossRef]

26. Stenger-Kovács, C.; Lengyel, E.; Crossetti, L.O.; Üveges, V.; Padisák, J. Diatom ecological guilds as indicators of temporally changing stressors and disturbances in the small Torna-stream, Hungary. Ecol. Indic. 2013, 24, 138-147. [CrossRef]

27. Körner, C. Scaling from species to vegetation: The usefulness of functional groups. In Biodiversity and Ecosystem Function; Schulze, E.D., Mooney, H.A., Eds.; Springer: Berlin, Germany, 1994; pp. 117-140.

28. Grime, J.P. Plant Strategies, Vegetation Processes and Ecosystem Properties, 2nd ed.; Wiley: Chichester, UK, 2001.

29. Tapolczai, K.; Bouchez, Á.; Stenger-Kovács, C.; Padisák, J.; Rimet, F. Trait-based ecological classifications for benthic algae: Review and perspectives. Hydrobiologia 2016, 776, 1-17. [CrossRef]

30. Lange, K.; Liess, A.; Piggott, J.J.; Townsend, C.R.; Matthaei, C.D. Light, nutrients and grazing interact to determine stream diatom community composition and functional group structure: Diatom responses to light, nutrients and grazing. Freshw. Biol. 2011, 56, 264-278. [CrossRef]

31. Lengyel, E.; Padisák, J.; Stenger-Kovács, C. Establishment of equilibrium states and effect of disturbances on benthic diatom assemblages of the Torna-stream, Hungary. Hydrobiologia 2015, 750, 43-56. [CrossRef]

32. Ter Braak, C.J.F.; Verdonschot, P.F.M. Canonical correspondence analysis and related multivariate methods in aquatic ecology. Aquat. Sci. 1995, 57, 255-289. [CrossRef]

33. Ter Braak, C.J.F.; Šmilauer, P. CANOCO Reference Manual and CanoDraw for Windows User's Guide: Software for Canonical Community Ordination (Version 4.5); Microcomputer Power: Ithaca, NY, USA, 2002.

34. Hudon, C.; Gagnon, P.; Amyot, J.-P.; Letourneau, G.; Jean, M.; Plant, C.; Rioux, D.; Deschenes, M. Historical changes in herbaceous wetland distribution induced by hydrological conditions in Lake Saint-Pierre (St. Lawrence River, Quebec, Canada). Hydrobiologia 2005, 539, 205-224. [CrossRef]

35. Hammer, Ø.; Harper, D.A.T.; Ryan, P.D. PAST: Paleontological Statistics Software Package for Education and Data Analysis. Palaeontol. Electron. 2001, 4, 9.

36. Gerecke, R.; Cantonati, M.; Spitale, D.; Stur, E.; Wiedenbrug, S. The challenges of long-term ecological research in spring in the northern and southern Alps: Indicator groups, habitat diversity, and medium-term change. J. Limnol. 2011, 70, 168-187. [CrossRef]

37. Van Dam, H.; Mertens, A.; Sinkeldam, J. A coded checklist and ecological indicator values of freshwater diatoms from the Netherlands. Neth. J. Aquat. Ecol. 1994, 28, 117-133.

38. Giller, P.; Malmqvist, B. The Biology of Streams and Rivers; Oxford University Press: New York, NY, USA, 1998; pp. 1-296.

39. Smith, H.; Wood, P.J. Flow permanence and macroinvertebrate community variability in limestone spring systems. Hydrobiologia 2002, 487, 45-58. [CrossRef]

40. Falasco, E.; Bona, F. Diatom community biodiversity in an Alpine protected area: A study in the Maritime Alps Natural Park. J. Limnol. 2011, 70, 157-167. [CrossRef]

41. Cantonati, M.; Ortler, K. Using spring biota of pristine mountain areas for long-term monitoring. Hydrology, Water Resources and Ecology in Headwaters. IAHS Publ. 1998, 248, 379-385.

42. Maes, J.; Paracchini, M.L.; Zulian, G.; Dunbar, M.B.; Alkemade, R. Synergies and trade-offs between ecosystem service supply, biodiversity, and habitat conservation status in Europe. Biol. Conserv. 2012, 155, 1-12. [CrossRef]

43. Grime, J.P. Competitive exclusion in herbaceous vegetation. Nature 1973, 242, 344-347. [CrossRef]

44. Penning, W.; Mjelde, M.; Dudley, B.; Hellsten, S.; Hanganu, J.; Kolada, A.; Van Den Berg, M.; Poikane, S.; Phillips, G.; Willby, N.; et al. Classifying aquatic macrophytes as indicators of eutrophication in European lakes. Aquat. Ecol. 2008, 42, 237-251. [CrossRef]

45. Toman, M.J.; Grošelj, A.M.; Zelnik, I. The influence of selected factors on the distribution of epilithic diatoms in a torrential river the Kamniška Bistrica (Slovenia). Acta Bot. Croat. 2014, 73, 447-463. [CrossRef] 
46. Cantonati, M.; Pipp, E. Longitudinal and seasonal differentiation of epilithic diatom communities in the uppermost sections of two mountain spring-fed streams. Verh. Int. Ver. Limnol. 2000, 27, 1591-1595. [CrossRef]

47. B-Béres, V.; Török, P.; Kókai, Z.; Lukács, Á.; Krasznai, E.T.; Tóthmérész, B.; Bácsi, I. Ecological background of diatom functional groups: Comparability of classification systems. Ecol. Indic. 2017, 82, 183-188. [CrossRef]

48. Porter, S.D.; Mueller, D.K.; Spahr, N.E.; Munn, M.D.; Dubrovsky, N.M. Efficacy of algal metrics for assessing nutrient and organic enrichment in flowing waters. Freshw. Biol. 2008, 53, 1036-1054. [CrossRef]

49. Allan, J.D.; Castillo, M.M. Stream Ecology, 2nd ed.; Springer: Dordrecht, The Netherlands, 2007; p. 436.

50. Smucker, N.J.; Vis, M.L. Using diatoms to assess human impacts on streams benefits from multiple-habitat sampling. Hydrobiologia 2010, 654, 93-109. [CrossRef]

51. Jones, J.I.; Duerdoth, C.P.; Collins, A.L.; Sear, D.A. Interactions between diatoms and fine sediment. Hydrol. Process. 2014, 28, 1226-1237. [CrossRef]

52. Balanč, T. Diversity of Diatom Communities in Different Habitats of the Limnocrene Spring Zelenci. Master's Thesis, University of Ljubljana, Biotechnical Faculty, Ljubljana, Slovenia, December 2016.

53. Grillas, P.; Gauthier, P.; Yaverkovski, N.; Perennou, C. Mediterranean Temporary Pools 1; Station Biologique de la Tour du Valat: Arles, France, 2004.

54. URS Infrastructure \& Environment UK Limited. South Stream Offshore Pipeline-Bulgarian Sector. Espoo Notification Document, URS-EIA-REP-201147, Published on 31 January 2013. Available online: http:/ / www.moew.government.bg/static/media/ups/tiny/file/Industry/EIA/Transgranichni_ EIA_procedures/notifkatsia_Morski_gazoprovod_en.pdf (accessed on 19 March 2018).

(C) 2018 by the authors. Licensee MDPI, Basel, Switzerland. This article is an open access article distributed under the terms and conditions of the Creative Commons Attribution (CC BY) license (http:/ / creativecommons.org/licenses/by/4.0/). 